\title{
STRENGHTH ANALYSIS OF HIP JOINT REPLACEMENT REVISION IMPLANT
}

\author{
PAWEe SKOWRONEK \\ Clinic of Orthopaedics and Traumatology, Regional Hospital and Jan Kochanowski University Kielce, Poland \\ e-mail: pawel_skowronek@interia.pl
}

Krzysztof Twardoch, Piotr Skawiński

Warsaw University of Technology, Institute of Machine Design Fundamentals, Warszawa, Poland

e-mail: krzysztof.twardoch@pw.edu.pl; psk@simr.pw.edu.pl

MARCEL ŻOENIERZ

Silesian University of Technology, Department of Mining Mechanisation and Robotisation, Gliwice, Poland e-mail: marcel.zolnierz@polsl.pl

\begin{abstract}
The subject of the article is the evaluation of the strength of revision implants made of titanium or tantalum alloy, used during bone reconstruction of a hip joint while potentially using additional stabilizing screws, necessary due to significant bone loss. The article provides a preliminary strength analysis of implants, indispensable for further evaluation of strength limitations due to the risk of implant damage depending on the structure and number of additional screw holes. In the human locomotor system, the hip joint is the joint with the most load, hence the main problem is to establish an adequate load model which ought to be assumed for the needs of implant strength analysis. It is found necessary to perform a short, analytical review of the existing hip joint load models from the point of view of choosing the proper one, considering evaluation of implant strength by means of numerical studies using FEM. Differences in the implant load distribution depending on the used material are shown.
\end{abstract}

Keywords: implant, implant strength, prosthesis, hip joint, material loss

\section{Introduction}

The treatment method that WHO considers the one which completely resolved symptoms and deformations resulting from Degenerative Joint Disease (DJD) is currently the primary Total Hip Replacement (THR). With higher life expectancy of patients, the number of people suffering from advanced degenerative lesions of joints is growing (DJD). Having reduced mortality resulting from heart and cardiovascular diseases within the last two decades, the number of patients suffering from DJD and treated with THR has grown. It has become a wider problem, also in reference to biological and mechanical aspects of prostheses degenerating bone tissue, which is currently the object of a few technical studies, e.g. evaluating the strength of bone cement in configuration with titanium implants and decreased quality of bone tissue (Benouis et al., 2016). Together with the number of primary joints replacements, the number of secondary-revision procedures is also growing, consisting in replacing prostheses with the new ones, e.g. due to pelvic bone or femur defects. Unfortunately, they are often implanted in acetabulum bone with bone losses that need procedures using modular reconstruction implants. These implants must possess appropriate strength and elasticity, enabling own load, must provide a reliable and multidirectional primary stabilization in bone tissue and secondary osseointegration of bone 
tissue in the implant. Thus, it is more and more common to use porous revision implants during joint reconstruction, which allows one to replace bone tissue with metal elements. The most commonly used are so called "full" ones, which possess only the external porous structure (most often hydroxyapatite layer) (Dorman et al., 2011) and "trabecular metal" type of implants with full spatial porous architecture enabling reconstruction of the bone tissue into the implant (Dorman et al., 2011). The applied implants are made of titanium and its alloys or of tantalum. The percentage composition of the applied metals is up to the producer. In most cases, titanium implants are made of titanium alloy with addition of rare metals such as Vanadium (Ti-6Al-4V-ELI) and Niobium (Ti-6Al-7Nb). In the case of spatial tantalum implants, only a tantalum foam sintered powder is used. It is the material with better bone biocompatibility and more biologically neutral for the organism, in comparison with rare metals used in titanium alloys. The implants are manufactured in different shapes and sizes, which allows one to fully or partially adjust them to bone losses, leading to reconstruction of anatomy with proper biomechanics of the joint. The essence of proper implant functioning is, apart from osteointegration and mechanical strength, lowest risk of allergic effects or cytotoxicity of metal ions (especially in the case of implants containing vanadium and niobium, each interference or damage of the structure during implantation may result in rare metal ions secretion). Standard manufactured implants contain primary holes which enable stabilization with a patient's bone by means of screws (Bobyn et al., 1999; Dorman et al., 2011; Hacking et al., 2000). The elements are interconnected using polymethylmethacrylate (PMMA) (Bobyn et al., 1999; Hacking et al., 2000; Meneghini et al., 2010). Each implant is characterized by proper elasticity, resulting from the applied metal i.e. Young's elasticity modulus $E$, determining linear strength. It has to be borne in mind, however, that when mechanically interfering with an implant (related to drilling additional fixing holes) during non-standard stabilization, the fatigue strength of an implant $R z$ may decrease as well as further damages may occur. It results from the change in strain and may require remodeling of stiffness and strength. Performed preliminary studies are supposed to evaluate the strength of tantalum "trabecular metal" type of implants and titanium mixed with niobium (Ti-6Al-7Nb) implants, which possess standard holed enabling stabilization with a patient's bone using screws. The research material presented in the article constitutes a starting point for research of strength evaluation of implants weakened by the holes drilled for the needs of potential additional stabilization and, at the same time, draws attention to the risk of mechanical consequences of excessive weakening of an implant and secondary biological risk of leaving drilling products behinds, especially those of rare metals.

\section{State of hip joint load}

In order to evaluate the risk of mechanical consequences of excessive weakening of an implant, it is decided appropriate to define the state of load by means of Finite Element Method (FEM). The main problem is to define the implant load model which must be assumed for the purpose of such an analysis. From the point of view of mechanics, precisely theory of machines and mechanisms, a hip joint is a III-class kinematic pair - spherical, enabling reciprocal spherical movement. In the human movement system, the hip joint is one of the biggest kinematic nodes, possessing three degrees of freedom $(s=3)$. The occurrence of additional degrees of freedom, connected with an incomplete close of the node is defined as hip joint instability (Harris, 1992). Transferring loads of the spine to lower extremities by means of pelvis, involving the hip joint occurs in conditions of a very complex movement (Fig. 1). It has to be borne in mind, that the hip joint together with skeletal system of the pelvic rim, connects the upper part of the human body with lower extremities by means of a complex system of muscles, tendons and ligaments. Interactions between the femur head and acetabulum as well as stresses of the muscle system 
taking part in movement, determines the state of load of the entire skeletal system of the hip joint. The load of the hip joint is directly dependent on body weight and activities performed by a human during walking - it constitutes a complex system of forces and moments. In the hip joint, movement may occur around three main axes. Usually, a particular movement caused by a contraction of the appropriate muscle is prevalent and determines the essential function of the hip joint to which a system of external and internal forces is applied. The external forces are: weight related to body mass, support actions, and forces resulting from interactions of other objects with the human body. The internal forces are mainly forces resulting from muscle interactions. Evaluation of directions and values of these forces is very difficult due to a large number of muscles and place of their application (muscle attachments) (Madej, 2008). Furthermore, values and directions of loads occurring in the hip joint vary in different phases of gait (Bergman et al., 1993, Bergman et al., 2001; Będziński and Ścigała, 2004; Dąbrowska-Tkaczyk, 1999; Dragan, 1992; Madej and Ryniewicz, 2007; Popovic et al., 2004, Włodarski, 2005).

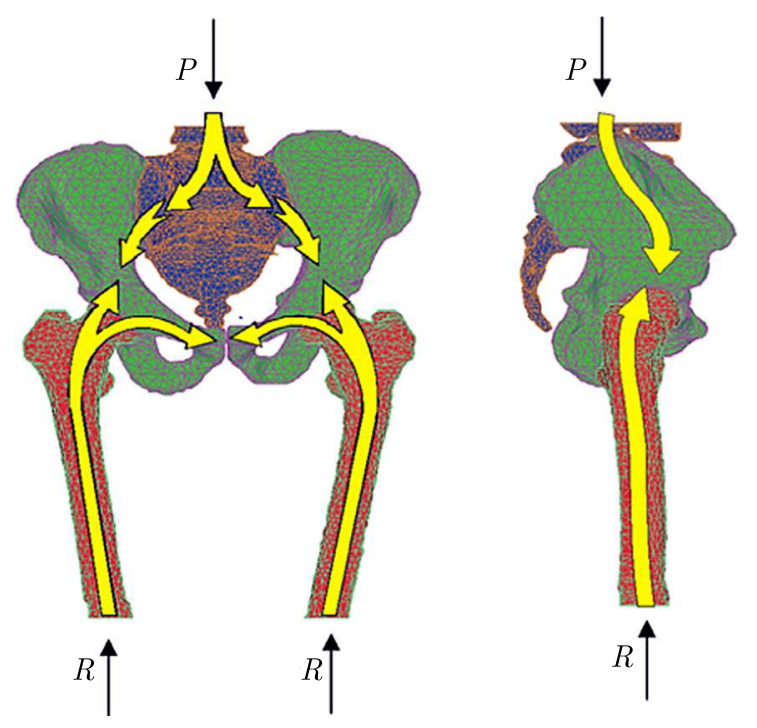

Fig. 1. Transfer of loads from the spine to lower extremities (Będziński, 1997)

During gait, the center of gravity of the body $\mathrm{S}$ also changes, and moves in the direction opposite to the loaded extremity (Fig. 2). Additionally, the loads in the hip joint depend on phases of foot contact with the ground. Movements in other planes occur: bow-hyperextension, ante-version and retroversion, as well as rotational movements.

The rule is to simulate static conditions in the load phase of one extremity, standing on both feet and in the phase of heel contact with the ground. Additionally, in vivo research is performed on the values of forces occurring in the hip joint in different phases of gait, especially in the phases, in which the highest load occurs: while standing on one foot, going up the stairs, getting up a chair. The values of forces occurring in the hip joint in patients with implanted a telemetric Moore-type implant were studied by Rydell. The research was continued by Bergman and Rohlmann, who defined vectors of forces influencing endoprosthesis head in a patient with full hip alloplasty (Dragan, 2004).

In experiments on biomechanics of hip joint, mechanical properties, especially stiffness and strength against impact stresses of constructed implants, are studied and physiological models of force and load distribution in the hip joint before and after endoprosthesis implantation are devised. Thus, the most often conducted research applies computer techniques using numerical simulation based on physical models, with holographic interferometry method or with application of resistance strain gauges (Dragan, 2004; Madej, 2008). 


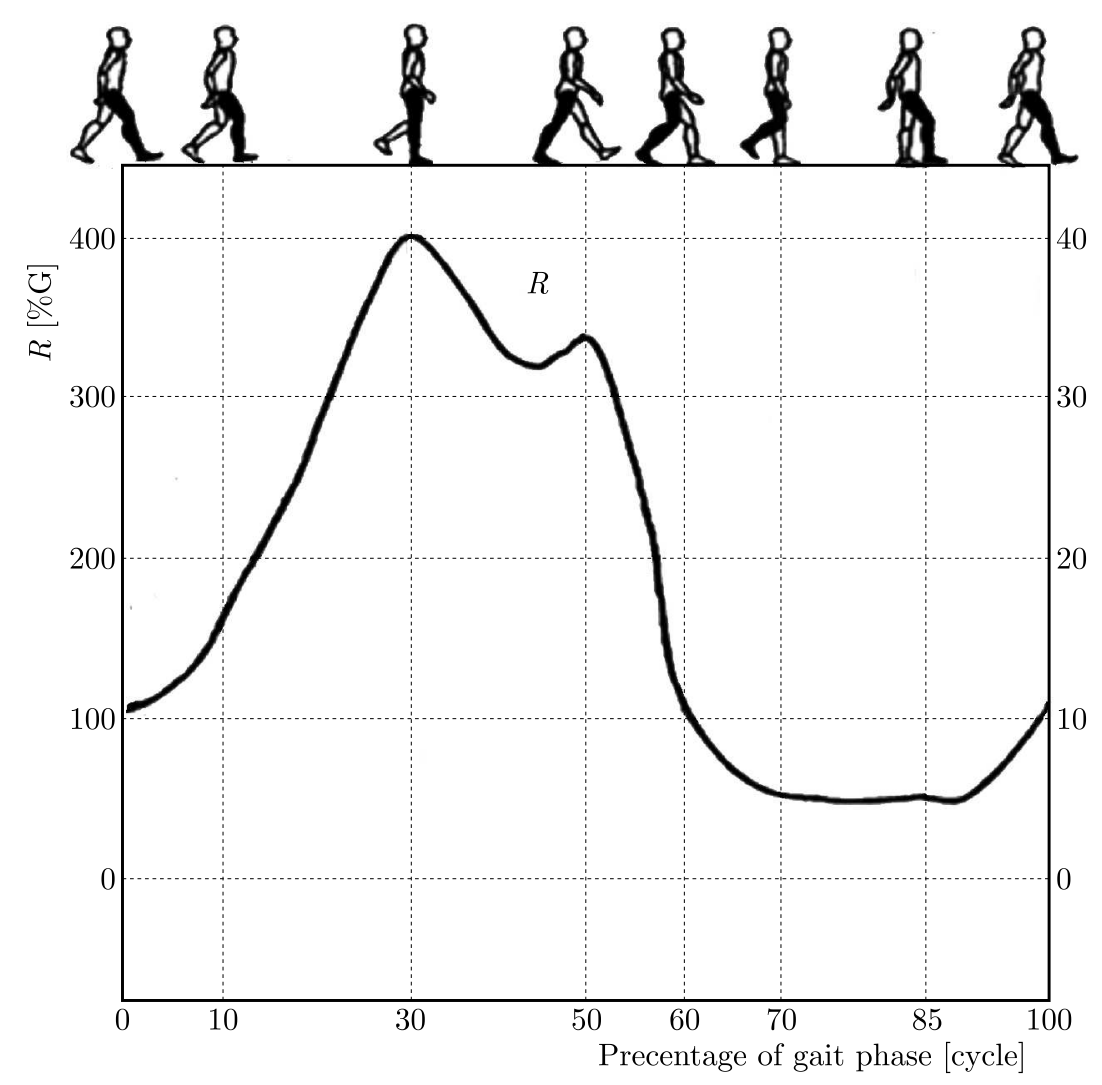

Fig. 2. The course of forces expressed as percentage of the body weight in the hip joint load in the gait cycle (according to Bergman) (Będziński, 1997)

\section{Identification of the hip joint load model}

The research on hip joint mechanics in numerous research centers has lod to creation of multiple models of the hip joint load, e.g. Pauwels', Maquet's, Bombeli's, Huiskes', Bergman's and Będziński's models (Bergman et al., 1993, 1995; Bernakiewicz and Będziński, 1999; Będziński, 1997; Bombeli, 1983; Maquet, 1985; Pauwels, 1976). Researchers, in their majority, agree that while modelling the hip joint load, the following have to be taken into consideration (Będziński, 1997):

- gluteus muscles, for lateral-medial loads,

- biceps femoris muscle, significant in front-to-back interactions,

- iliotibial band of abductors (tractusiliotibialis),

- band of abductors, more significant in femur load than band of adductors,

- a group of rotator muscles, during simulation of the extremity movement in the sagittal plane, which causes - due to their function and location - turning moment of femur.

In the light of all the above, the identification of hip joint load model is an exceptionally difficult and crucial task, considering theoretical studies aimed at strength evaluation from the perspective of e.g. deformation or risk of implant damage.

One of the most common hip joint load models is Pauwels' model, which presents two cases of the hip joint load: two-feet load and standing on one lower extremity (Fig. 3a). The resultant vector of the force $R$ is directed at the rotation point, which is the anatomical center of the femur head. In Pauwels' model, it is assumed that during unilateral extremity load, the total value of the force loading hip joint results from the interaction between the body weight and forces of periarticular muscles (Madej, 2008). 


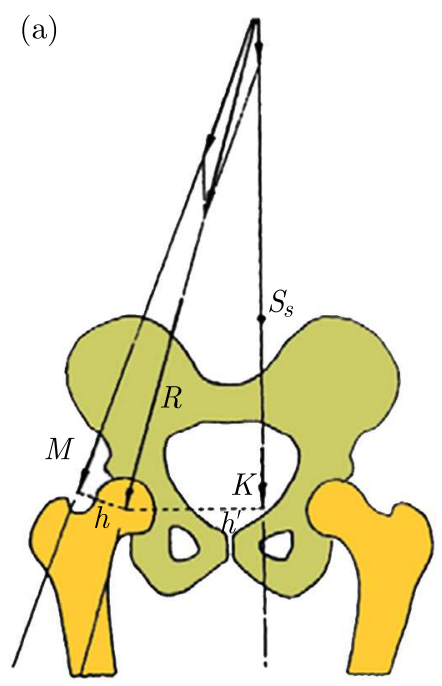

(b)

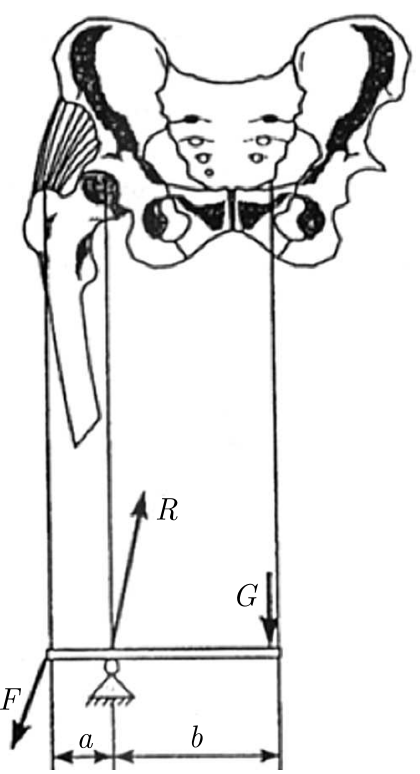

Fig. 3. (a) Hip joint load model (according to Pauwels) during movement, the phase of one leg load: $S_{5}$ - body center of gravity, impact of torso, hand-arms, head, without the other lower extremity, $K$ - resultant force of body weight impact, $M$ - abductor muscle impact, $R$ - resultant reaction of impact on the femur head (Bernakiewicz, 1994). (b) Model of two-armed lever modelling loads of the femur head while standing on one leg (Będziński, 1997)

Relations of loads in the hip joint are brought to a two-armed lever, in which the point of support is in the middle of the hip joint (Fig. 3b). Such an attitude towards the issue constitutes a significant simplification of a complex state of load in the hip joint, dependent on various factors (Będziński, 1997; Pauwels, 1976). Analysis of loads based on a two-armed lever is approximately valid only in the case of the state of balance, when the body center of gravity is in the coronal plane. Performing any kind of movement will cause a change in the location of the body center of gravity, which results in the change in the state of load - directions and values of forces coming from groups of muscles which become activated in order to maintain balance of the body (Będziński, 1997).

The role of iliotibial band is presented differently by Maquet's model (Fig. 4a), which is a modification of Pauwels' model. In Maquet's model, tension of the external band of thigh fascia lata is caused by the abductor muscle. The band is simulated as a tie running along the femoral shaft from the knee joint to pelvic bone. The tie is based on the great trochanter of the femur and can slide on it. The impact of the iliotibial band modeled in this way gives an additional horizontal force, which stabilizes the hip joint. Due to a different, in comparison with other models, consideration of the impact of muscles, Maquet's model is more accurate in terms of the upper anatomy of the lower extremity (Będziński, 1997; Madej, 2008).

Both hip joint load models (Maquet's and Pauwels') present a system of forces impacting the pelvis (together with the upper part of the lower extremity) only in the coronal plane.

The model of the hip joint load, additionally considering the role of rotator muscles $R_{u}$ which cause turning of the femur in relation to the pelvis (Fig. 4b), based on Maquet's model, is shown by Będziński (Będziński and Ścigała, 2004; Będziński, 1997). In this model, the iliotibial band can also move along the external surface of the great trochanter of femur. The loading system is constituted by the resultant forces of the hip joint: impact of the weight of torso on the femur head $R$, abductors $M_{a}$ and the iliotibial band $M, T$ (sliding on the great trochanter of femur) and rotational forces $R_{u}$. The author states (Będziński and Ścigała, 2004; Będziński, 1997; Madej and Ryniewicz, 2007; Madej, 2008; Ryniewicz and Madej, 2001, 2002) that the devised model 

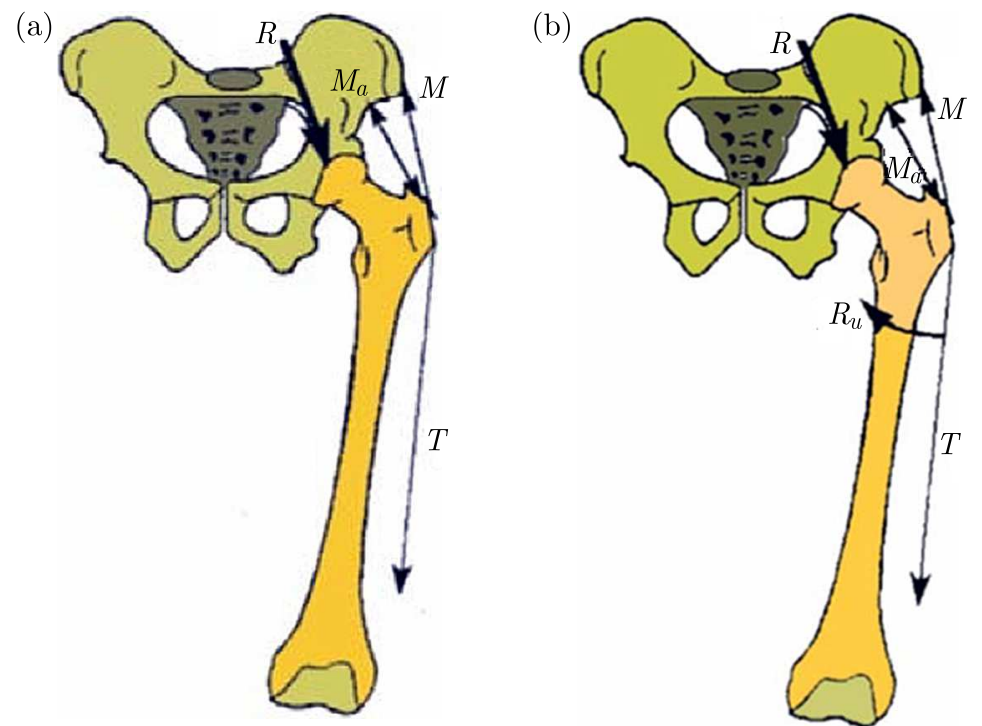

Fig. 4. (a) Maquet's hip joint load model (Będziński, 1997). (b) Będziński's model (devised at Zakład Doświadczalnej Analizy Konstrukcji Inżynierskich i Biomechanicznych) (Będziński and Ścigała, 2004; Będziński, 1997)

results from experimental studies conducted on physical models. The model groups the basic forces acting within functioning of the hip joint.

The aim of the analysis of the state of strain and deformation in an endoprosthesis of the hip joint, having an analytically revised model of the loads of this joint, is to assume the spatial hip joint load model according to Będziński.

\section{Hip joint load}

While defining loads for the needs of the studies, the model devised at Division of Experimental Analysis of Engineering and Biomechanical Structures of Wrocław University of Science and Technology by prof. R. Będziński has been assumed, as well as literature data taken from M. Bernakiewicz's PhD Dissertation (Bernakiewicz, 1999), and a unique software for analyzing gait HIP98, which enables to define values of forces and moments for each case of movement. The value of load for the studies is assumed based on Table 1 (Madej, 2008), in which values of the resultant force $F$ acting upon the femur head in the case of performing movement are compiled. The values obtained from HIP98 software for different velocities of gait of particular patients and various phases - have been assumed after (Madej, 2008), based on literature (Bergman etal, 2001; Bernakiewicz, 1999; Bernakiewicz and Będziński, 1999). The aim of obtaining a comparative reference in terms of reliability of literature data, own studies have been performed at Clinic of Orthopedics and Rehabilitation of the 2nd Faculty of Medicine of Medical University of Warsaw, which include cases of patients (taking into account sex) occurring most often statistically, considering weight and load. The studies were performed for the following conditions: an $80 \mathrm{~cm}$ step forward without weight transfer and with total temporary transfer of weight to one foot and leap (maximum temporal result) of $100 \mathrm{~cm}$ from the platform for different weights (Table 2).

While performing a comparative analysis, it was concluded that in none of the cases the value of $1000 \mathrm{~N}$ of patient's body weight was exceeded. Arbitrarily, in strength analysis, it was decided to assume a certain surplus of load impacting the hip implant, the value of the vector of the resultant force $F=300 \mathrm{~N}$. The load was assumed with a slight reserve of value in the light 
Table 1. Values of reaction forces on the femur head for particular patients (Madej, 2008)

\begin{tabular}{|c|c|c|c|c|c|c|c|c|c|}
\hline \multirow{2}{*}{\multicolumn{2}{|c|}{$\begin{array}{cc}\text { Phase of gait } & \text { Patient } \\
\text { Resultant force } \% 100 \mathrm{BW}\end{array}$}} & \multicolumn{4}{|c|}{$\begin{array}{c}\text { Phase of heel contact } \\
\text { with the ground }\end{array}$} & \multicolumn{4}{|c|}{$\begin{array}{l}\text { Phase of standing } \\
\text { on one foot }\end{array}$} \\
\hline & & $F_{x}$ & $F_{y}$ & $F_{z}$ & $F$ & $F_{x}$ & $F_{y}$ & $F_{z}$ & $F$ \\
\hline \multirow{3}{*}{$\begin{array}{l}\text { H.S. } \\
\text { body weight } \\
860 \mathrm{~N}\end{array}$} & $\begin{array}{l}\text { Slow gait } \\
3.81 \mathrm{~km} / \mathrm{h}\end{array}$ & 49 & 17 & 216 & 222 & 47 & 19 & 188 & 195 \\
\hline & $\begin{array}{l}\text { Normal gait } \\
4.41 \mathrm{~km} / \mathrm{h}\end{array}$ & 49 & 22 & 231 & 237 & 42 & 16 & 175 & 181 \\
\hline & $\begin{array}{l}\text { Fast gait } \\
5.11 \mathrm{~km} / \mathrm{h}\end{array}$ & 55 & 23 & 268 & 274 & 46 & 12 & 181 & 187 \\
\hline \multirow{3}{*}{$\begin{array}{l}\text { P.F. } \\
\text { body weight } \\
980 \mathrm{~N}\end{array}$} & $\begin{array}{l}\text { Slow gait } \\
3.08 \mathrm{~km} / \mathrm{h}\end{array}$ & 29 & 43 & 215 & 221 & 35 & 34 & 234 & 239 \\
\hline & $\begin{array}{l}\text { Normal gait } \\
3.71 \mathrm{~km} / \mathrm{h}\end{array}$ & 29 & 35 & 197 & 202 & 30 & 23 & 206 & 209 \\
\hline & $\begin{array}{l}\text { Fast gait } \\
4.46 \mathrm{~km} / \mathrm{h}\end{array}$ & 29 & 30 & 187 & 192 & 33 & 26 & 207 & 211 \\
\hline \multirow{3}{*}{$\begin{array}{l}\text { K.W. } \\
\text { body weight } \\
980 \mathrm{~N}\end{array}$} & $\begin{array}{l}\text { Slow gait } \\
3.81 \mathrm{~km} / \mathrm{h}\end{array}$ & 61 & 17 & 202 & 212 & 68 & 3 & 205 & 216 \\
\hline & $\begin{array}{l}\text { Normal gait } \\
4.05 \mathrm{~km} / \mathrm{h}\end{array}$ & 67 & 20 & 230 & 240 & 59 & -1 & 179 & 189 \\
\hline & $\begin{array}{l}\text { Fast gait } \\
4.64 \mathrm{~km} / \mathrm{h}\end{array}$ & 73 & 19 & 251 & 262 & 58 & 4 & 167 & 177 \\
\hline \multirow{3}{*}{$\begin{array}{l}\text { Average } \\
\text { for all } \\
\text { patients }\end{array}$} & $\begin{array}{l}\text { Slow gait } \\
3.60 \mathrm{~km} / \mathrm{h}\end{array}$ & 47 & 27 & 214 & 221 & 51 & 25 & 217 & 224 \\
\hline & $\begin{array}{l}\text { Normal gait } \\
4.09 \mathrm{~km} / \mathrm{h}\end{array}$ & 47 & 23 & 210 & 216 & 54 & 8 & 200 & 207 \\
\hline & $\begin{array}{l}\text { Fast gait } \\
4.74 \mathrm{~km} / \mathrm{h}\end{array}$ & 52 & 26 & 237 & 244 & 47 & 1 & 180 & 186 \\
\hline
\end{tabular}

of not sufficient knowledge of the actual state of the hip joint load, according to the authors, with regard to not yet fully identified parameters of this load.

\section{Geometry and conditions of the hip joint load}

The assumed geometry of the cup implant system subject to strength analysis in conditions of the static load is shown in Fig. 5. The analyzed implants are a standard version, having preliminary holes which enable stabilization with a patient's bone using screws. For the assumed geometry of the model, tetra-meshing is applied, i.e. uneven division of the solid model continuum into finite elements of Tet1o type (quadratictetrahedron) is applied. Three identical cylindrical elements symbolize screws, which are screwed during a surgical procedure.

Strength analysis has been performed for the "trabecular metal" type of implants and titanium implants with the addition of niobium (Ti-6Al-7Nb), which possess primary holes enabling stabilization with a patient's bones using screws.

Mechanical properties for materials:

- "trabecular metal" - are assumed based on the article (Medlin et al., 2004)

\begin{tabular}{|c|c|c|c|}
\hline $\begin{array}{c}\text { Young's modulus } \\
{[\mathrm{MPa}]}\end{array}$ & $\begin{array}{c}\text { Poisson's } \\
\text { ratio }\end{array}$ & $\begin{array}{c}\text { Yield strength } \\
{[\mathrm{MPa}]}\end{array}$ & $\begin{array}{c}\text { Tangent modulus } \\
{[\mathrm{MPa}]}\end{array}$ \\
\hline \hline 3100 & 0.35 & $48.2( \pm 5.9)$ & 310 \\
\hline
\end{tabular}


Table 2. Values of forces without and with transfer of weight on one foot and during leap

\begin{tabular}{|c|c|c|c|c|}
\hline Sex & $\begin{array}{c}\text { Weight } \\
{[\mathrm{N}]}\end{array}$ & $\begin{array}{c}\text { Step forward } \\
\text { without }[\mathrm{N}]\end{array}$ & $\begin{array}{c}\text { Step forward } \\
\text { with }[\mathrm{n}]\end{array}$ & $\begin{array}{c}\text { Leap } \\
{[\mathrm{N}]}\end{array}$ \\
\hline \hline $\mathrm{M}$ & 780 & 220 & 760 & 790 \\
\hline $\mathrm{M}$ & 870 & 270 & 880 & 910 \\
\hline $\mathrm{K}$ & 560 & 190 & 550 & 570 \\
\hline $\mathrm{K}$ & 630 & 200 & 620 & 640 \\
\hline $\mathrm{K}$ & 720 & 220 & 720 & 730 \\
\hline $\mathrm{M}$ & 880 & 240 & 880 & 890 \\
\hline $\mathrm{M}$ & 670 & 220 & 680 & 700 \\
\hline $\mathrm{K}$ & 770 & 210 & 770 & 770 \\
\hline $\mathrm{M}$ & 710 & 220 & 720 & 740 \\
\hline $\mathrm{M}$ & 680 & 210 & 690 & 690 \\
\hline $\mathrm{K}$ & 720 & 210 & 710 & 710 \\
\hline $\mathrm{M}$ & 740 & 220 & 740 & 750 \\
\hline $\mathrm{K}$ & 810 & 210 & 810 & 780 \\
\hline $\mathrm{K}$ & 510 & 180 & 500 & 520 \\
\hline $\mathrm{K}$ & 550 & 190 & 550 & 550 \\
\hline $\mathrm{M}$ & 760 & 220 & 750 & 760 \\
\hline $\mathrm{K}$ & 780 & 200 & 780 & 780 \\
\hline $\mathrm{K}$ & 810 & 200 & 800 & 810 \\
\hline $\mathrm{M}$ & 800 & 220 & 800 & 820 \\
\hline $\mathrm{K}$ & 620 & 200 & 620 & 620 \\
\hline $\mathrm{M}$ & 640 & 220 & 640 & 650 \\
\hline $\mathrm{M}$ & 680 & 220 & 680 & 680 \\
\hline $\mathrm{M}$ & 590 & 210 & 590 & 600 \\
\hline $\mathrm{K}$ & 670 & 210 & 660 & 670 \\
\hline $\mathrm{M}$ & 750 & 220 & 750 & 760 \\
\hline $\mathrm{M}$ & 910 & 250 & 900 & 930 \\
\hline $\mathrm{M}$ & 870 & 230 & 830 & 840 \\
\hline $\mathrm{K}$ & 710 & 220 & 700 & 720 \\
\hline $\mathrm{K}$ & 770 & 210 & 760 & 770 \\
\hline $\mathrm{K}-\mathrm{N}$ & & & \\
\hline
\end{tabular}

$\mathrm{K}$ - female, $\mathrm{M}$ - male

- titanium alloy with addition of niobium (Ti-6Al-7Nb) - assumed based on article (Li et al., 2014)

\begin{tabular}{|c|c|c|c|}
\hline $\begin{array}{c}\text { Young's modulus } \\
{[\mathrm{MPa}]}\end{array}$ & $\begin{array}{c}\text { Poisson's } \\
\text { ratio }\end{array}$ & $\begin{array}{c}\text { Yield strength } \\
{[\mathrm{MPa}]}\end{array}$ & $\begin{array}{c}\text { Tangent modulus } \\
{[\mathrm{MPa}]}\end{array}$ \\
\hline \hline 110000 & 0.36 & $\min 800(880-950)$ & 5000 \\
\hline
\end{tabular}

The analyzed case is the one of the implant load being in contact with the pelvic bone, as shown in Fig. 6. The pelvic bone is modeled conventionally, as a slice of a spherical cylinder, to which an augment cup implant is attached by means of $500 \mathrm{~N}$ tension screws (Fig. 6a), the pelvic bone is fixed (Fixed Support), as illustrated in Fig. 6b (blue spherical surface). The direction of impact of the acetabulum force $F$ on the augment is illustrated by Fig. 7a. The load system of the implant by vectors of screw tension forces $F=500 \mathrm{~N}$ (axial forces resulting from fixing the cup augment to the pelvis) and the vector of the resultant force $F=300 \mathrm{~N}$ is illustrated by Fig. $7 \mathrm{~b}$. 

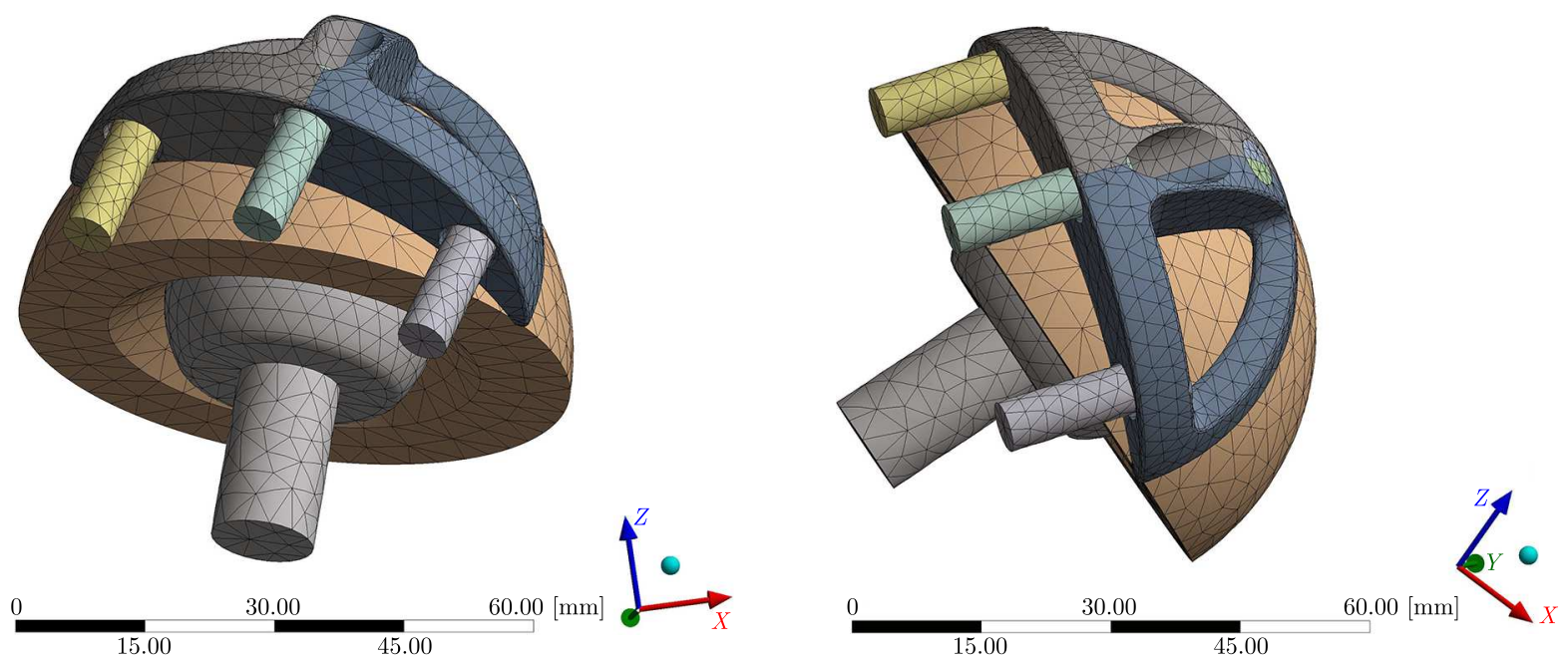

Fig. 5. Meshing process continuum of the cup implant model

(a)

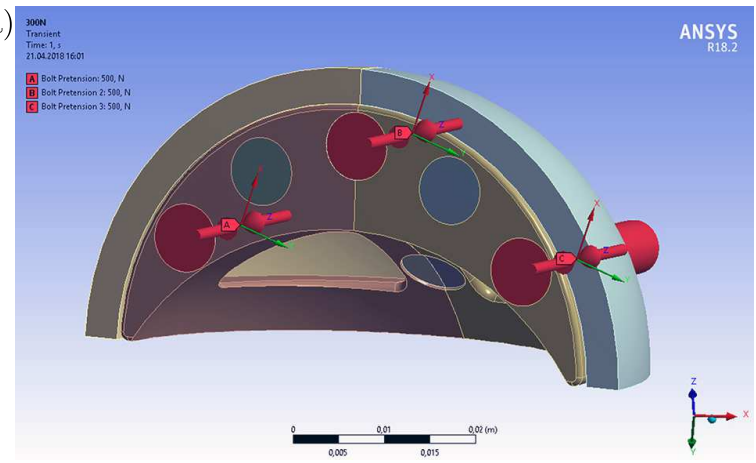

(b)

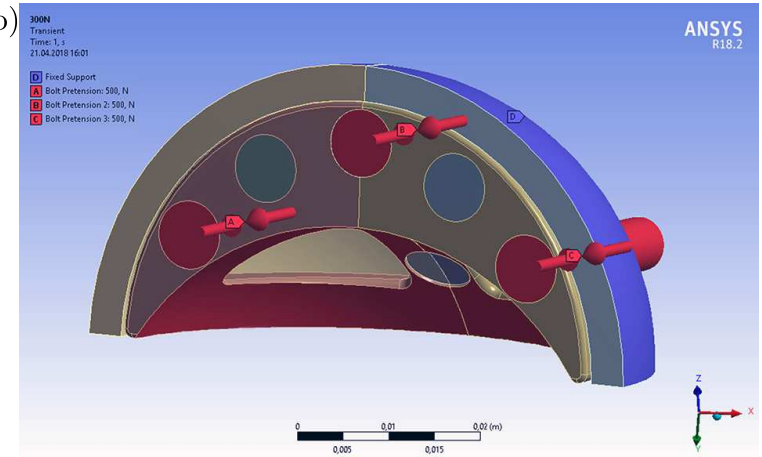

Fig. 6. Fixing the implant (cup augment) to the pelvic bone: (a) tension of screws (500 N), (b) fixed support of the pelvic bone (blue spherical surface)

(a)

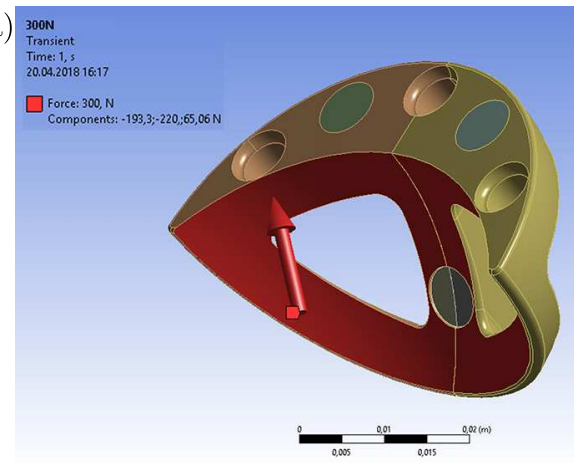

ANSYS
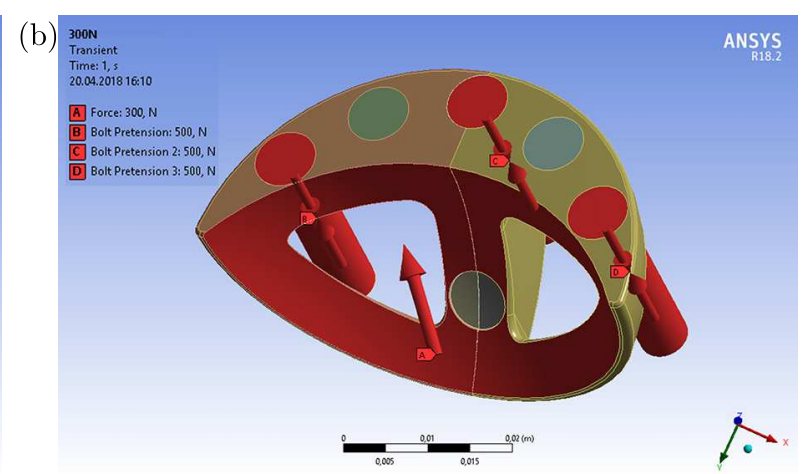

Fig. 7. System of implant (cup augment) load: (a) vector of the resultant force $F=300 \mathrm{~N}$ impacting the augment, (b) vectors of screw tension forces $F=500 \mathrm{~N}$ (axial forces resulting from fixing the augment to the pelvis) and the vector of the resultant force

Distribution (maps) of strain reduced according to HMH Hypothesis (Huber-Mises-Hencky hypothesis of specific energy of shear modulus) obtained by means of FEM analysis for the case of the "trabecular metal" type of implants and titanium implants with addition of niobium (Ti-6Al-7Nb) are shown in Figs. 8 and 9. Distributions (maps) of total deformations of the cup augment for these two cases of implant materials are shown in Figs. 10 and 11, respectively. 

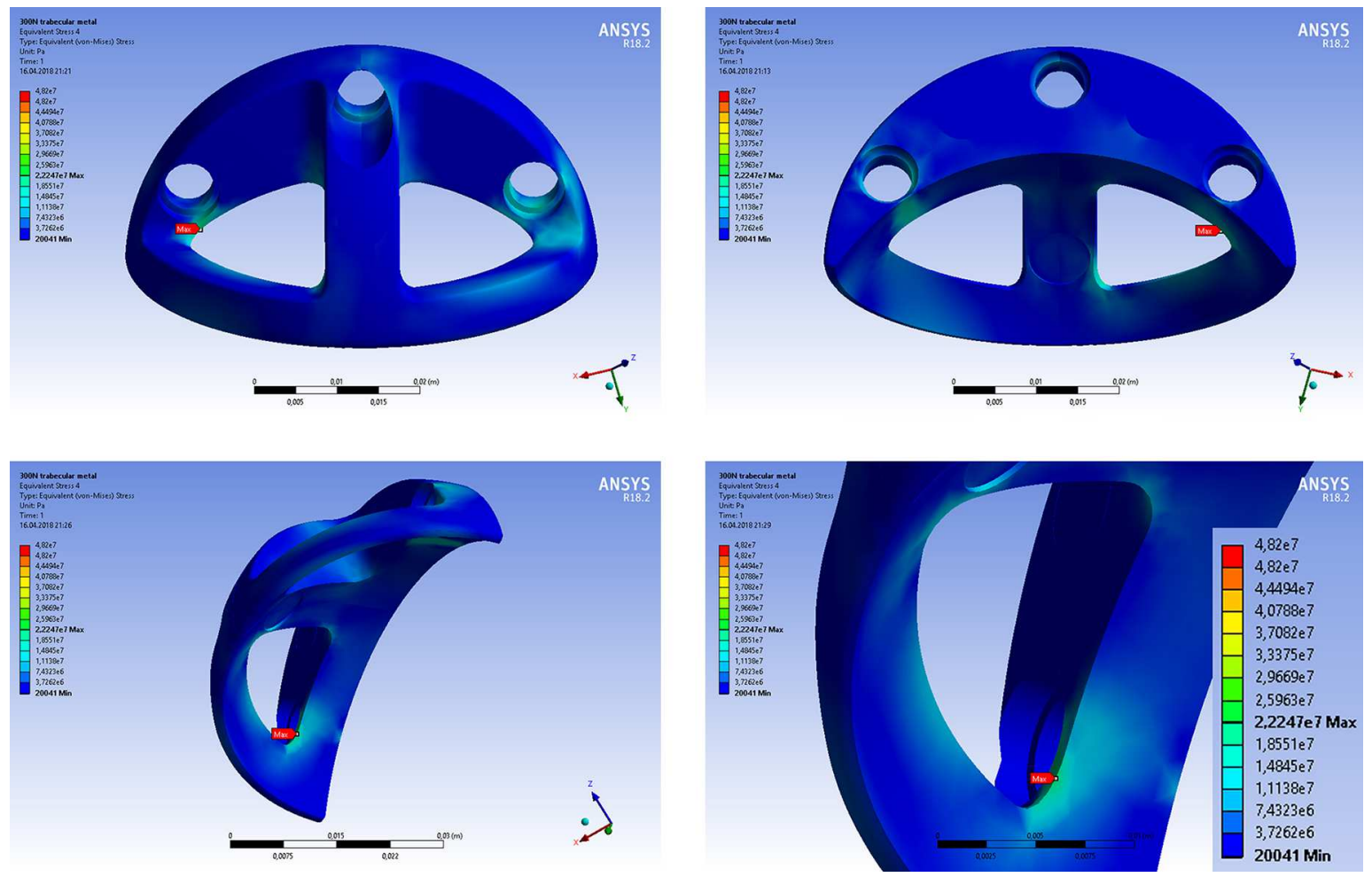

Fig. 8. Map of reduced strain according to HMH - "trabecular metal" tantalum implant loaded with a $300 \mathrm{~N}$ force
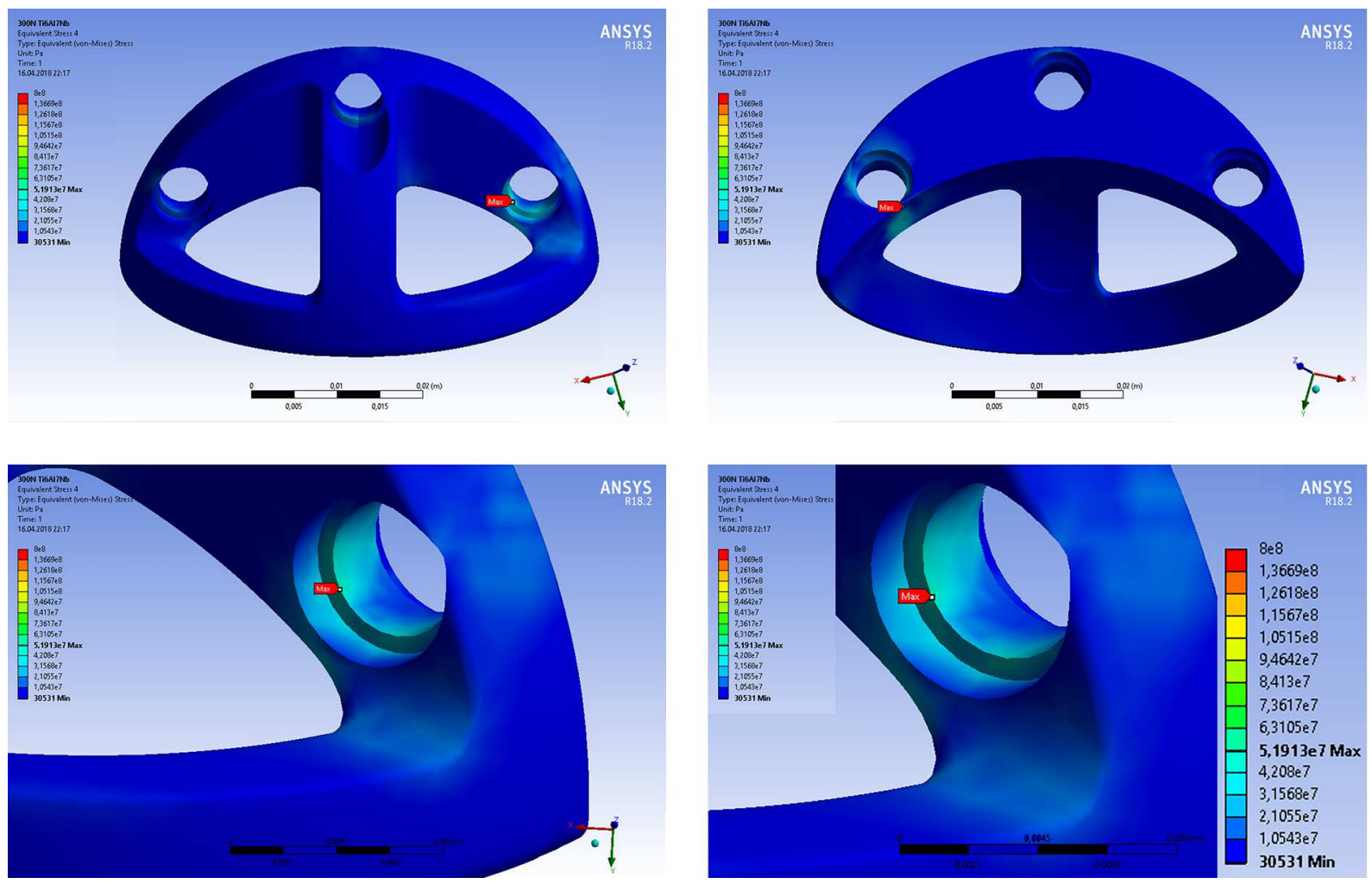

Fig. 9. Map of reduced strain according to $\mathrm{HMH}$ - titanium Ti-6Al-7Nb implant loaded with a $300 \mathrm{~N}$ force 
(a)

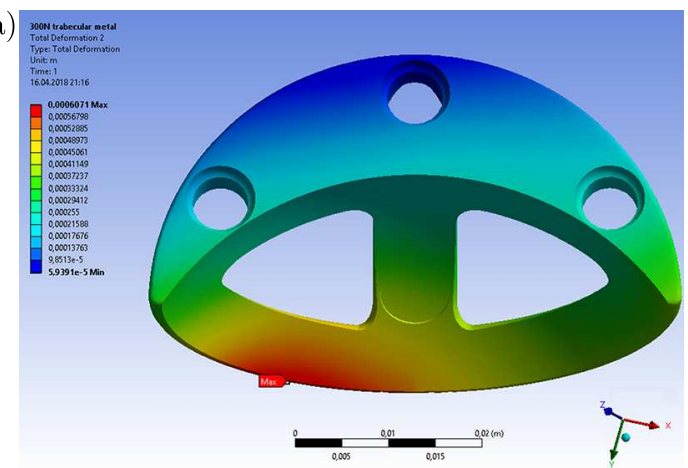

(b)

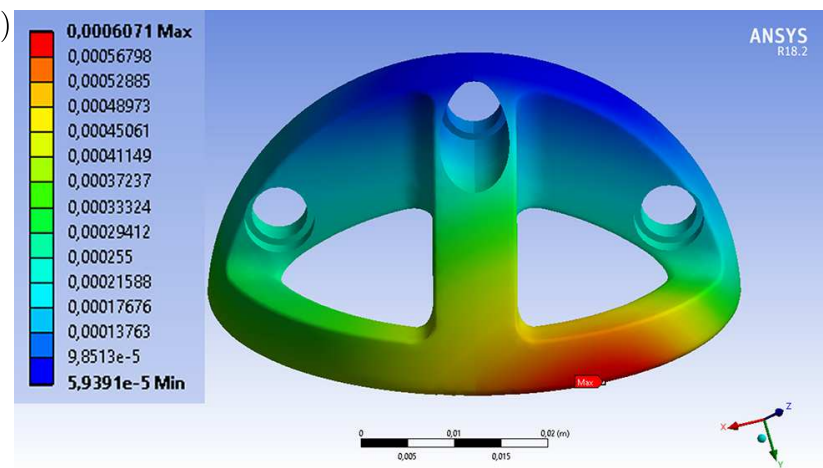

Fig. 10. Map of total deformations - "trabecular metal" tantalum implant loaded with a $300 \mathrm{~N}$ force

(a)

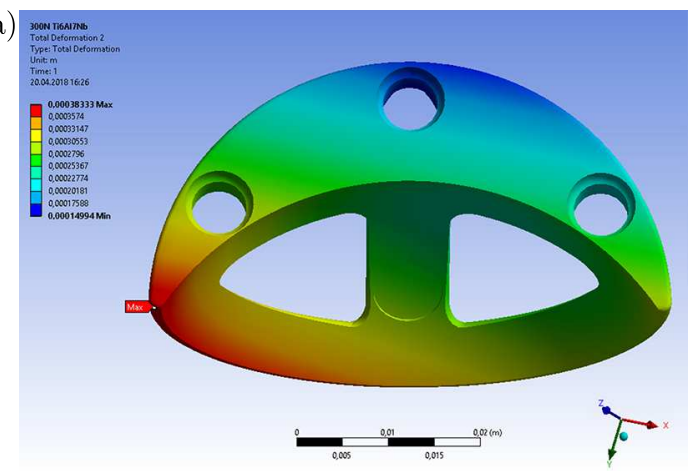

(b)

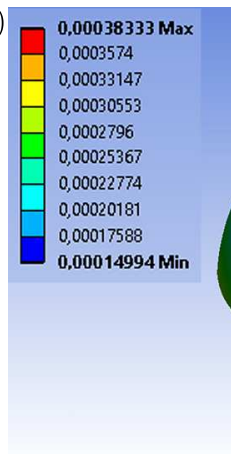

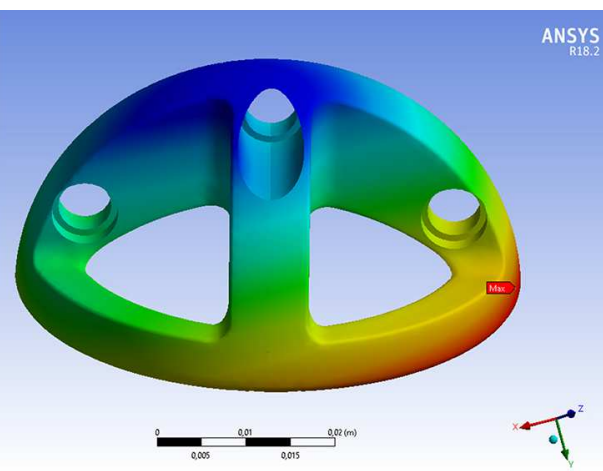

Fig. 11. Map of total deformations - titanium Ti-6Al-7Nb implant loaded with a $300 \mathrm{~N}$ force

In neither of the analyzed cases the values of reduced strains HMH reach the assumed ductility border $R e_{\text {Tantalum }}=48.2 \mathrm{MPa}$ and $R e_{\text {Titanium }}=800 \mathrm{MPa}$. For the assumed maximum force $F=300 \mathrm{~N}$ loading of implants, the highest values of reduced strain $\mathrm{HMH}$ reach about $46 \%$ $R e_{t m}=22.3 \mathrm{MPa}$ for the "trabecular metal" tantalum implant and $6.5 \% R e_{T i}=52 \mathrm{MPa}$ for titanium Ti-6Al-7Nb implant, respectively. The maximum values of the reduced strain according to HMH occur around the fixing holes and are connected with the concentration of strains around them.

Local concentrations of strains around holes result from screw tension forces, and are connected with the assumed boundary conditions. In the actual system, where the analyzed implant will cooperate fixed to the pelvic bone (especially after it bonds with the bone), the risk of implant damage as a result of strain concentration will not occur. It has to be stressed, however, that the maximum total deformations occur in the lower rim of the cup implant and may result from the pressure of the augment on the pelvic bone due to uneven pressure during acetabulum impact. The values of maximum deformations amount to about $0.607 \mathrm{~mm}$ for the "trabecular metal" tantalum implant, and to $0.383 \mathrm{~mm}$ for the titanium implant respectively. It can be noticed, however, that the total deformations around the holes for the implant made of the "trabecular metal" material are about $50 \%$ smaller, and do not exceed approximately $0.3 \mathrm{~mm}$. For the implant made of Ti-6Al-7Nb, a slight displacement of the simulated pressure of the augment to the pelvic bone occurred (along the lower rim of the cup implant towards the sharp edge), thus relatively higher values of total deformations around the hole occur, amounting to approximately $80 \%$ of the maximum, but do not exceed $0.3 \mathrm{~mm}$.

The analyzed issue is considered as a static analysis. Apart from the value of the load force $F$, a fatigue character of the operation of the analyzed system, subject to permanent movement load, ought to be noticed. 


\section{Conclusions}

The conducted preliminary simulation studies enable strength evaluation of "trabecular metal" tantalum implants and titanium implants with addition of niobium (Ti-6Al-7Nb). The results of performed numerical analyses indicate that implants with standard holes (i.e. without mechanical interference connected with non-standard stabilization with a patient's bone) fulfill the strength requirements in conditions of the maximum strain in the assumed implant load system.

It has to be kept in mind, however, that during non-standard stabilization connected with drilling additional fixing holes, the implant fatigue strength $R z$ may decrease, which may lead to further damage. So far, it has not been studied how mechanical interference with the implant structure and their modification by drilling more holes influences the mechanical properties of such a system, i.e. change in implant ductility in terms of implant strength after drilling additional holes. The reports on the strength of the structure after drilling the holes, as well as after prolonged functioning of such implants, are scarce (Bobyn et al., 1999; Levine et al., 2006; Meneghini et al., 2010; Meneghini et al., 2010). Attention needs to be drawn to a series of significant issues connected with the risk of:

- decreasing strength and elasticity of an implant modified with holes,

- damage to prosthesis articulation caused by pieces of metal which remain after drilling and/or prior loosening of the implant,

- migration of particles in the circulatory system, nephrotoxicity while using alloys with addition of $\mathrm{Al}, \mathrm{Ni}$ and $\mathrm{V}$, influence of metal ions and implant corrosion around the prosthesis and weakening of implant osseointegration.

Further studies ought to identify:

- The influence of additional holes in medical implants made of Ti and Ta alloys on strength properties of such implants. During bone reconstruction of the hip joint, it is often required to perform additional holes for the needs of stabilization techniques connected with a significant bone loss.

- The influence of dependence of the remaining in the surgical field mass of metal ions on prosthesis tribology.

- The influence of the mass of tantalum and titanium particles and rare metal ions (such as $\mathrm{Ni}$ and $\mathrm{V}$ ) on body toxicity.

- The risk of influence of metal ions and implant corrosion on periarticular tissues, together with the increase in the mass of tantalum and titanium, aluminum, niobium and vanadium particles.

Furthermore, studies should to be aimed at:

- Development of implant material with high mechanical properties, least possibly susceptible to weakening due to interference with the implant structure.

- Development of a technique of maximum removal of metal particles from the surgical field.

The above-mentioned issues define the authors' goals in terms of further numerical studies of implants made of the "trabecular metal" and Ti-6Al-7Nb material.

\section{References}

1. Benouis A., Boulenouar A., Serirer B., 2016, Finite element analysis of the behavior of a crack in the orthopedic cement, Journal of Theoretical and Applied Mechanics, 54, 1, 277-284

2. Bergman G., Graichen F., Rohlmann A., 1993, Hip joint loading durnig walking and running, measured in two patients, Journal Biomechanics, 26, 969-990. 
3. Bergman G., Graichen F., Rohlmann A., 1995, Is stair case walking a risk for the fixation of hip implants? Journal Biomechanics, 28, 532-533

4. Bergman G., Deuretzbaher G., Heller M., Graichen F., Rohlmann A., Strauss J., DudA G.N., 2001, Hip contact forces and gait patterns from routine activities, Journal of Biomechanics, 34, 859-871

5. Bernakiewicz M., 1999, Elaboration the strain-stresses criteria for the selection of hip joint implants (in Polish), Ph.D. Thesis, Wroclaw University of Science and Technology, Wrocław

6. Bernakiewicz M., BęDziński R., 1999, An analysis of the stress state of femur under extreme load conditions (in Polish), Zeszyty Naukowe Konferencji Mechaniki Stosowanej, 9, 15-21

7. Bernakiewicz M., 1994, The concept of constructional solution of the prosthetic nail of hip joint cementless endoprosthesis (in Polish), Biomechanika, 94 (Prace Naukowe Instytutu Konstrukcji i Eksploatacji Politechniki Wrocławskiej, nr 75, Seria: Konferencje nr 21, Wrocław), 19-22

8. BęDziński R., 1997, Engineering Biomechanics. Selected Issues (in Polish), Oficyna wydawnicza Politechniki Wrocławskiej, Wrocław

9. Będziński R., ŚcigaŁA K., 2004, Biomechanics of the hip joint and knee joint (in Polish), [In:] Biocybernetyka i Inżynieria Rehabilitacyjna, 5, Będziński R. (Edit.), Akademicka Oficyna Wydawnicza Exit, Warszawa

10. Bobyn J.D., Stackpool G.J., Hacking S.A., Tanzer M., Krygier J.J., 1999, Characteristics of bone ingrowth and interface mechanics of a new porous tantalum biomaterial, Journal of Bone and Joint Surgery. British Volume, 81, 5, 907-914

11. Bombeli R., 1983, Structure and Function in Normal and Abnormal Hips, Springer-Verlag, Berlin

12. DąBrowska-TKACZYK A., 1999, Modeling stress and strain distribution in the pelvic bone during quesi-static backward rotation, Proceedings Biomechanics 99, Acta of Bioengineering and Biomechanics $V, \mathbf{1}, 93-96$

13. Dorman T., Kmieć K., Pogonowicz E., Sibiński M., Synder M., KozŁowski P., 2011, Revision treatments in large acetabulum cavities using cup augment (in Polish), Chirurgia Narzadu Ruchu i Ortopedia Polska, 76, 1, 21-24

14. Dragan S., 1992, Studies on the influence of construction of the prosthetic nail of cementless endoprosthesis and the distribution of forces in femur under the influence of loads on disturbances of primary stability (in Polish), Ph.D. Thesis, Medical Academy, Wrocław

15. Dragan S., 2004, Clinical and biomechanical aspects of osteointegration course of hip joint endoprostheses (in Polish), [In:] Biocybernetyka i Inżynieria Rehabilitacyjna, 5, Będziński R. (Edit.), Akademicka Oficyna Wydawnicza Exit, Warszawa

16. Hacking S.A., Bobyn J.D., Toh K., TÄnzer M., Krygier J.J., 2000, Fibrous tissue ingrovrth and attachment to porous tantalum, Journal of Biomedical Materials Research, 52, 4, 631-638

17. Harris W.H., 1992, The problem is osteolysis, Clinical Orthopaedics, 247, 6-11

18. Levine B.R., Sporer S., Poggie R.A., Delia Valle C.J., Jacobs J.J., 2006, Experimental and clinical performance of porous tantalum in orthopedic surgery, Biomaterials, 27, 4671-4681

19. Li Y., Yang C., Zhao H., Qu S., Li X., Li Y., 2014, New developments of Ti-based alloys for biomedical applications, Materials, 7, 1709-1800

20. Madej T., Ryniewicz A.M., 2007, Simulation of contact mechanics with a complex load condition in the hip joint endoprosthesis (in Polish), Materiaty konferencyjne, IV Krakowskie Warsztaty Inżynierii Medycznej, Kraków

21. Madej T., 2008, Modeling the movement zone of the hip joint endoprosthesis in the aspect of biomaterials (in Polish), Ph.D. Thesis, AGH University of Science and Technology, Kraków

22. Maquet P.G.J., 1985, Biomechanics of the Hip, Berlin 
23. Medlin D.J., Charlebois S., Swarts D., Shetty R., Poggie R.A., 2004, Metallurgical characterization of a porous Tantalum biomaterial (Trabecular metal) for orthopaedic implant applications, Medical Device Materials: Proceedings of the Materials and Processes for Medical Conference, S. Shrivastava (Edit.), 394-398

24. Meneghini R.M., Ford K.S., McCollough C.H., Hahssen A.D., Lewallen D.G., 2010, Bone remodeling around porous metal cementless acetabular components, Journal Arthroplasty, 25, 5, 741-747

25. Meneghini R.M., Meyer C., Buckley C.A., Hanssen A.D., Lewallen D.G., 2010, Mechanical stability of novel highly porous metal acetabular components in revision total hip arthroplasty, Journal of Arthroplasty, 25, 3, 337-341

26. Pauwels F., 1976, Biomechanics of the Locomotor Apparatus, Berlin

27. Popovic M., Hofmann A., Herr H., 2004, Angular momentum regulation during human walking: biomechanics and control, Proceedings - IEEE International Conference on Robotics and Automation, ICRA 2004, New Orleans, LA, USA, 3, 3, 2405-2411

28. Ryniewicz A.M., MadeJ T., 2001, The influence technology parameters on tribology properties films have been obtained by chemical vapour deposition, Proceedings of the 12th International DAAAM Symposium Technical University of Vienna, 417-418

29. Ryniewicz A.M., MadeJ T., 2002, Analysis of stresses and displacements in the working zone of the hip joint endoprosthesis (in Polish), Mechanika w Medycynie, 6, 127-134

30. WŁodarski J., 2005, Stability of hip joint cement endoprostheses in the light of histological, numerical and experimental studies (in Polish), Bio-Algorithms and Med-Systems, 1, 2, 197-204 